\section{THE EFFECT OF UTILIZING SILICA FUME AND EGGSHELL ASH ON THE GEOTECHNICAL PROPERTIES OF SOFT KAOLIN CLAY}

Muhammad Syamsul Imran Zainia, Muzamir Hasana*, Ling Sin Yiea, Khairil Azman Masria, Ramadhansyah Putra Jayaa, Masayuki Hyodob, Michael James Winterc

aDepartment of Civil Engineering, College of Engineering, Universiti Malaysia Pahang, 26300 Kuantan, Pahang, Malaysia

bGraduate School of Science and Technology for Innovation, Yamaguchi University, Ube, Japan

cHokoku Engineering Co., Ltd., Daikoku-cho, Toyonaka-shi, Japan
Article history

Received

1 June 2021

Received in revised form

14 October 2021

Accepted

7 November 2021

Published Online

20 December 2021

*Corresponding author muzamir@ump.edu.my

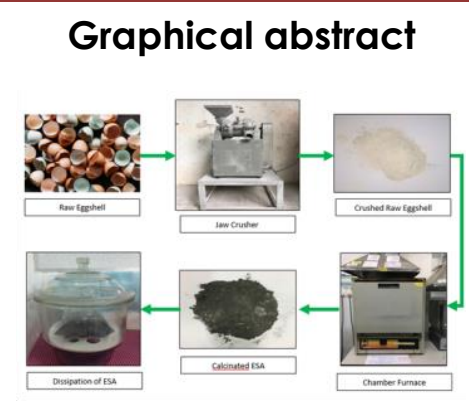

\begin{abstract}
The application of chemical stabilizer in soil stabilization can effectively reduce the negative environmental impact in the construction industry. However, the stabilization of soft clay remains a challenge due to the costly and non-eco-friendly materials such as cement and lime. This research demonstrates the combination of SF and ESA in stabilizing the kaolin soils, based on the basic engineering properties and undrained shear strength (USS). Its effect was studied via the inclusion as cement replacement material in kaolin soil at 2, 4 and $6 \%$ (by weight of dry soft kaolin clay soil) of SF and ESA substitutions of 3, 6 and $9 \%$ (by weight of dry soft kaolin clay and SF content). The result shows a considerably lower specific gravity ( $4.9 \%$ reduction), reduced plasticity index (PI) (48.4\% reduction), decreased maximum dry density (MDD) (5.5\% reduction), increased optimum moisture content (OMC) (8.7\% increment), and higher USS (68.8\%). In conclusion, the combinations of SF and ESA as soil stabilization agents successfully enhance the soil strength of the kaolin opening a route to the low cost and eco-friendly materials in soil stabilization.
\end{abstract}

Keywords: Soil Improvement, Silica Fume, Eggshell Ash, Strength Improvement, Kaolin

\begin{abstract}
Abstrak
Penerapan penstabil kimia dalam penstabilan tanah secara berkesan dapat mengurangkan kesan persekitaran negatif dalam industri pembinaan. Walau bagaimanapun, penstabilan tanah liat lembut tetap menjadi cabaran kerana bahan yang mahal dan tidak mesra alam seperti simen dan kapur. Penyelidikan ini menunjukkan gabungan SF dan ESA dalam menstabilkan tanah kaolin, berdasarkan sifat asas kejuruteraan dan kekuatan ricih tidak terlatih (USS). Kesannya dikaji melalui penyertaan sebagai bahan pengganti simen di tanah kaolin pada kadar 2, 4 dan 6\% (berat tanah tanah liat lembut kaolin kering) penggantian SF dan ESA 3, 6 dan 9\% (berat kaolin lembut kering kandungan tanah liat dan SF). Hasilnya menunjukkan graviti spesifik yang jauh lebih rendah (pengurangan 4.9\%), penurunan indeks keplastikan (PI) (pengurangan 48.4\%), penurunan kepadatan kering maksimum (MDD) (pengurangan 5.5\%), peningkatan kadar kelembapan optimum (OMC) (kenaikan $8.7 \%$, dan USS lebih tinggi (68.8\%). Kesimpulannya, kombinasi SF dan ESA sebagai agen penstabilan tanah berjaya meningkatkan kekuatan tanah kaolin yang membuka laluan ke bahan kos rendah dan mesra alam dalam penstabilan tanah.

Kata kunci: Peningkatan Tanah, Asap Silika, Abu Kulit Telur, Peningkatan Kekuatan, Kaolin

(c) 2022 Penerbit UTM Press. All rights reserved
\end{abstract}




\subsection{INTRODUCTION}

In the past few years, the main challenges that geotechnical engineers would have to tackle is the construction and execution of land developmental works on areas of the globe with a serious concentration of high swelling clayey soils [1, 2, 3, 4, 5]. Lack of consideration for infrastructure and building construction on soft soils is highly risky due to the high compressibility and low shear strength [6;7]. Among these types of soil, clay soil is known for its problematic properties by their innate capacity to undergo volumetric changes corresponding to changes in the moisture regime $[3,4,5,8,9]$.

Clay soil is flaky in shape with particle sizes less than $2 \mu \mathrm{m}$ (5 $\mu \mathrm{m}$ in some classification system) and usually has a very large surface area. The small size of the particle associated with a very large surface area cause the clay to exhibit high ability in retaining water, thus causing the swell-shrink characteristic when subject to moisture variations [3, 10]. Such expansive properties have made the clay soil become a troublesome soil that needs special treatment for the construction activity [11]. Therefore, it is crucial to enhance and improve the soil properties using stabilization techniques that can respond to the drastic demand situations.

The interaction of soil adjustment is generally used to improve the geotechnical and actual properties of the soil. The most recent technique for soil adjustment is to supplant the mismatched soil with more grounded materials like cement, seriously soil, geotextiles and geo-lattices [12]. As per the past research, a few added substances were utilized as settling specialists. A portion of these stabilizer added substances comprises different sorts of bitumen, pozzolanic added substances, lime and concrete. Soil adjustment or soil treatment with added substances is a well-informed and extremely savvy procedure that has been utilized to improve the sturdiness and mechanical properties of the extensive soils [5].

Traditionally, cement has been used massively for the soil stabilizer compared to other materials [13, 14]. However, the substantial creation fundamentally affects the natural quality. The production of concrete in the concrete industry is a significant wellspring of $\mathrm{CO}_{2}$ outflow and cause the release of unsafe ozone harming substances $[14,15,16]$. The concrete assembling interaction can deliver from as low as $600 \mathrm{~kg}$ to $1200 \mathrm{~kg}$ of $\mathrm{CO}_{2}$ emanation to the air for each metric ton of water-driven concrete created [8, 14, 17, 18, 19].

Thus, a decrease of concrete creation on the natural effect has been started by supplanting it with another maintainable material, for example, pozzolan (i.e eggshell ash, silica fume, fly ash, risk hush ash, etc.) [20]. To limit the adjustment costs, concrete supplanting with squander materials, like fly ash, rice husk ash and biomass ash has been generally applied practically speaking. Nevertheless, agro waste products have newly attracted the focus due to the massive availability of solid waste from this field [21].

Presently, most specialists are taking more noteworthy interests in the use of waste materials. Notwithstanding land occupation, the waste warehouse created from different assembling enterprises causes numerous natural issues too $[5,12]$. Therefore, efficient utilization of resources is one of the most important issues that should be highlighted today [22]. As of now, it has become evident that waste materials are utilized for different designing and geotechnical properties and lessen their ecological effect on the climate. Furthermore, utilizing waste materials have remarkable properties for some designing and geotechnical applications. The properties of waste materials like toughness, strength and high obstruction are required for the plan of the establishment of a structure and parkway development [4].

In this study, the material that is used as a soil stabilizing agent is eggshell ash (ESA) and silica fume (SF). Some studies have implemented calcium ions usage from sources such as limestone and eggshells as low-cost alternatives to pure calcium salts [23, 24]. The eggshells contain a limestone or calcium carbonate usually called calcite $\left(\mathrm{CaCO}_{3}\right)[25,26]$. Eggshell ash (ESA) is another bio-waste material that can be utilized to reduce the cement in concrete production [27]. Eggshells, the byproduct of eggs utilization, can establish an irritation in our current circumstance through unpredictable removal [29]. Additionally, the eggshells which is the hard external layer of an egg make up around $10 \%$ of the egg weight with a normal load of $60 \mathrm{~g}[25,26]$.

There is a slight addition of moving in egg creation worldwide and it is required to produce more than 8 million tons of eggshell squander each year [26]. Consequently, as the population keep growing, the eggshell waste will keep increasing [26, 29]. Moreover, the removal of ES is one of the enormous issues as it can deliver a bothersome smell and hypersensitivities. Along these lines, this will bring about understanding environmental issues that may request a legitimate treatment [29]. The eggshell comprises developing layers of $\mathrm{CaCO}_{3}$ that structure $95 \%$ of the shell [29]. With the permeable unpredictable molecule size of 2 to $900 \mathrm{~mm}$ that wealthy in calcite $\left(\mathrm{CaCO}_{3}\right)$ present in the ESA, it is additionally can be utilized for divider tile creation [29]. ESA is a useful stabilizing material for clay soil [30]. Besides, ESA also is a suitable material to replace part of lime in soil stabilization $[26,29]$ and can replace cement in improving the soil properties [26].

The high strength of concrete can be produced using silica-fume (SF) as a replacement for cement or by using an additive $[6,31]$. In the previous studies, SF was assimilated to the clay soil with the combination of other materials such as lime, cement, sawdust, bamboo slag, etc. and the results stated that the addition of SF can modify the properties of the soil and enhance the strength parameters of clay soil [6, $32,33]$. The introduction of SF contributed to higher 
compressive strength or thermal conductivity values ratios and greater compressive strength compared to the fly ash, due to the pore-filling and pozzolanic effect of silica fume itself [32; 33].

Hence, in this present study, the gap is filling with the potential of using the combination of SF and ESA in soft clay soil as a soil stabilization agent and a new alternative method to enhance the shear strength of the clay soils. Based on the previous study, there are a lot of researches conducted related to the usage of ESA in cement replacement material but only a few of them discussed the application of the ESA as a soil stabilizing agent. The optimum mixture between SF and ESA with the clay soils not only can enhance the shear strength of the soft clay soils but also lower the specific gravity, reduced the plasticity index (PI), decreased the maximum dry density (MDD), and increased the optimum moisture content (OMC). Thus making the silica fume-egg shell ash mixture a sustainable material for weak soil stabilizing agent which is environmentally friendly and cost-effective. Moreover, the correlation equation for the basic engineering properties was also established.

\subsection{METHODOLOGY}

\subsection{Materials}

Kaolin S300, purchased from Kaolin (M) San. Bhd. was used as the soil sample in this present research. It is a white colour clay (Figure 1(a)) manufactured in the laboratory and is fine in size. Kaolin, which is also known as kaolinite clay is a type of clay that either can be found in nature or made in the laboratory [11]. The type of SF (grey colour powder) used in this study was Scanfume (Figure 1 (b)), a densified SF for concrete, which has a very large surface area of a minimum of $15000 \mathrm{~m}^{2} / \mathrm{kg}$. The reactivity of the pozzolanic reaction is influenced by the total surface area of the SF.

As the total surface area greater, the reactivity of the pozzolanic reaction higher [11]. The raw chicken eggshells were collected from the restaurants in Kuantan, Pahang. The raw chicken eggshells were then washed, air-dried for seven (7) days, crushed and heated at $800^{\circ} \mathrm{C}$ for 1 hour by using the chamber furnace to generate the ESA. The ESA formed from calcination was grey in colour as was stored in a desiccator for 24 hours to cool down the ash and prevent the hydration process between ESA and moisture from the atmosphere as shown in Figure 1 (c). The preparation of eggshell ash is clearly shown in Figure 2. The availability and eco-friendly characteristics of eggshell waste were the reasons that eggshell ash been selected as the stabilizing agent in this study. It is also more cost-effective as compared with other ordinary soil stabilizer such as lime, cement and, etc $[25,29]$ up of the $\mathrm{CaCO}_{3}$ and transformed to $\mathrm{CaO}$ under the calcination process
[29]. The main chemical composition of kaolin, SF and ESA are shown in Table 1.

Table 1 Chemical composition of Kaolin, SF and ESA

\begin{tabular}{ccccc}
\hline Composition & Unit & Kaolin & SF & ESA \\
\hline $\mathrm{SiO}_{2}$ & $\%$ & 66.11 & 74.02 & 0.02 \\
$\mathrm{CaO}$ & $\%$ & 0.08 & 0.00 & 62.50 \\
$\mathrm{Al}_{2} \mathrm{O}_{3}$ & $\%$ & 19.25 & 0.45 & 0.01 \\
$\mathrm{~K}_{2} \mathrm{O}$ & $\%$ & 2.85 & 4.27 & 0.05 \\
$\mathrm{MgO}$ & $\%$ & 1.23 & 3.73 & 0.71 \\
$\mathrm{Fe}_{2} \mathrm{O}_{3}$ & $\%$ & 0.73 & 0.71 & 0.02 \\
\hline
\end{tabular}

\subsection{Experimental Methods}

The basic engineering properties of all of the materials were determined through the stated laboratory tests. Kaolin S300 was chosen instead of the natural soil is to control the standardization of the study. Next, the soft kaolin was treated with $2 \%, 4 \%$ and $6 \%$ of SF by the dry weight of the soil and the alterations in the physical, strength and compaction properties of soil were examined. Table 2 shows the sample coding that was used throughout this study. The percentage of SF that attributed to the maximum undrained shear strength (USS) was marked as the optimum SF content. This optimum SF content was then admixed with soft kaolin and $3 \%, 6 \%$, and $9 \%$ of ESA by the dry weight of the soil sample. The geotechnical characteristics of the soil mixture and the optimum ESA content corresponding to the maximum strength were then defined. The percentage of SF and ESA adopted in this present research were chosen based on the previous researches [30, 11]. The laboratory tests and standards that applied to study the engineering properties of kaolin, SF, ESA and the kaolin-SF-ESA mix were presented in Table 3.

Table 3 Standards of Laboratory Testing

\begin{tabular}{lc}
\hline \multicolumn{1}{c}{ Test } & Standard \\
\hline Mechanical Sieve Analysis & BS 1377: Part 2: 1990 \\
Hydrometer Test & BS 1377: Part 2: 1990 \\
Specific Gravity Test & BS 1377: Part 2: 1990 \\
Atterberg Limit & BS 1377: Part 2: 1990 \\
Standard Proctor Test & BS 1377: Part 4: 1990 \\
Unconfined Compression Test (UCT) & ASTM D2166 \\
\hline
\end{tabular}

In this examination, the unconfined pressure tests were performed to research the mechanical properties of kaolin, SF and ESA. Table 4 shows the details of kaolin, SF and ESA used for UCT test. Field Scanning electron microscopy (FESEM) tests were additionally led to notice the microstructure of the examples when blending the kaolin in with the SF and ESA. Additionally, the strength boundaries of the inward grinding point and attachment as per the Mohr-Coulomb rule were likewise decided. The specimens used for this test were prepared by 
compacting soil samples with an optimum water content of the soils. The examples were ready and compacted in a barrel-shaped steel form with the elements of $100 \mathrm{~mm}$ in high $\times 50 \mathrm{~mm}$ in diameter. Furthermore, to ensure the consistency of the example and the accuracy during the UCT test, the density of the example is controlled using consistent volume and control of the mass of the example. The unconfined pressure tests were led on examples at a pace of $0.5 \%$ to $2 \%$ each minute until shear failure. The correlations of the engineering properties of soft kaolin with the varying SF and ESA content was also established.

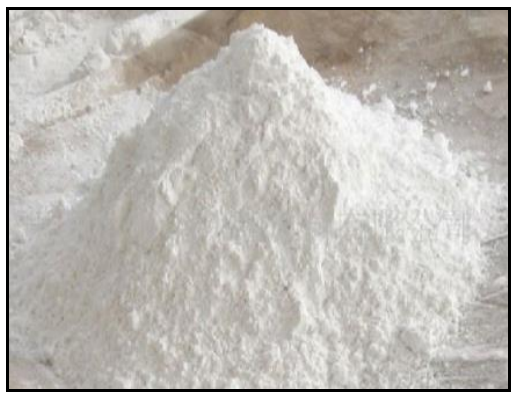

(a)

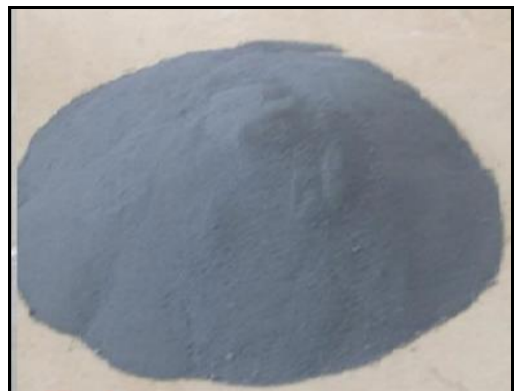

(b)

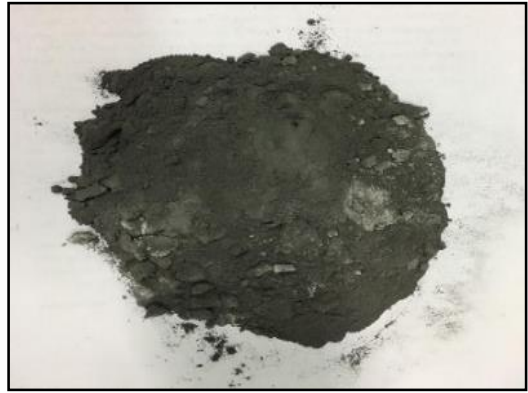

(c)

Figure 1 Materials used in the study; (a) Kaolin, (b) Silica Fume, (c) Eggshell Ash
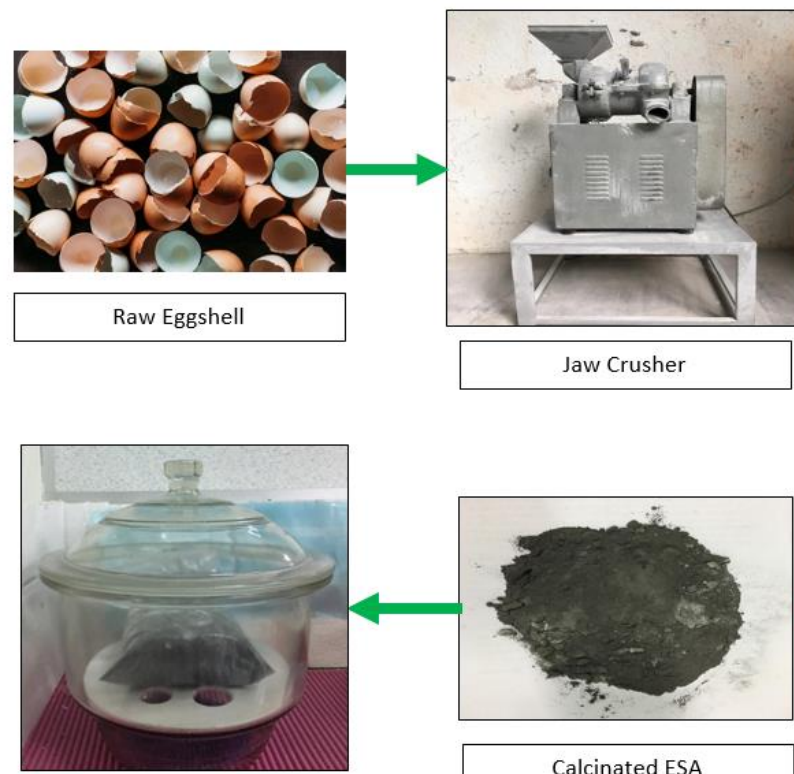

Dissipation of ESA
Jaw Crushe

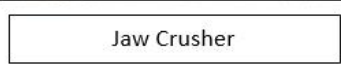

Crushed Raw Eggshell

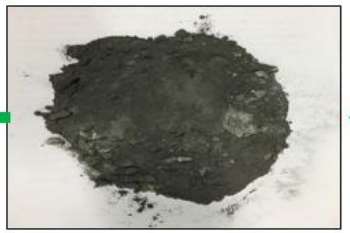

Calcinated ESA
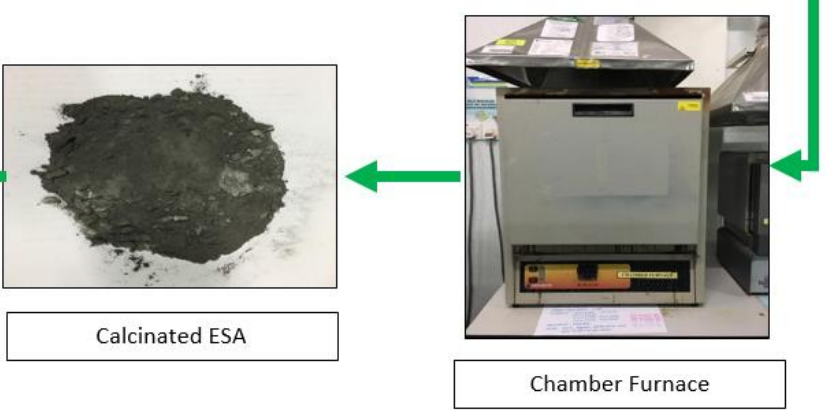

Figure 2 Preparation process for eggshell ash

Table 2 Samples Coding

\begin{tabular}{|c|c|c|c|c|}
\hline \multirow{2}{*}{ Sample } & \multirow{2}{*}{ Coding } & \multicolumn{3}{|c|}{ Content (\%) } \\
\hline & & Kaolin & SF & ESA \\
\hline Kaolin (Control) & K & 100 & - & - \\
\hline Kaolin with $2 \%$ of Silica Fume & K2SF & 98 & 2 & - \\
\hline Kaolin with $4 \%$ of Silica Fume & K4SF & 96 & 4 & - \\
\hline Kaolin with $6 \%$ of Silica Fume & K6SF & 94 & 6 & - \\
\hline Kaolin with $6 \%$ of Silica Fume and $3 \%$ of Eggshell Ash & K6SF3ESA & 91 & 6 & 3 \\
\hline Kaolin with $6 \%$ of Silica Fume and $6 \%$ of Eggshell Ash & K6SF6ESA & 88 & 6 & 6 \\
\hline Kaolin with $6 \%$ of Silica Fume and $9 \%$ of Eggshell Ash & K6SF9ESA & 85 & 6 & 9 \\
\hline
\end{tabular}


Table 4 Details of kaolin, SF and ESA used for UCT test

\begin{tabular}{|c|c|c|c|c|c|}
\hline Type of Sample & $\begin{array}{l}\text { Sample } \\
\text { Coding }\end{array}$ & Mass (g) & $\begin{array}{c}\text { Volume } \\
\left(\mathrm{cm}^{3}\right)\end{array}$ & $\begin{array}{c}M D D \\
\left(\mathrm{~g} / \mathrm{cm}^{3}\right)\end{array}$ & OMC (\%) \\
\hline Kaolin & K & 310 & 196.35 & 1.606 & 19.0 \\
\hline Kaolin + 2\% Silica Fume & K2SF & 310 & 196.35 & 1.550 & 19.5 \\
\hline Kaolin + 4\% Silica Fume & K4SF & 310 & 196.35 & 1.548 & 19.8 \\
\hline Kaolin + 6\% Silica Fume & K6SF & 310 & 196.35 & 1.522 & 20.4 \\
\hline Kaolin + 6\% Silica Fume + 3\% Eggshell Ash & K6SF3ESA & 310 & 196.35 & 1.555 & 19.7 \\
\hline Kaolin + 6\% Silica Fume + 6\% Eggshell Ash & K6SF6ESA & 310 & 196.35 & 1.525 & 20.5 \\
\hline Kaolin + 6\% Silica Fume + 9\% Eggshell Ash & K6SF9ESA & 310 & 196.35 & 1.517 & 20.8 \\
\hline
\end{tabular}

\subsection{RESULTS AND DISCUSSION}

\subsection{Basic Engineering Properties}

\subsubsection{Specific Gravity}

The specific gravity for Kaolin S300 is 2.64, which determined the kaolin as the kaolinite clay as mentioned by previous researchers which stated that the specific gravity for kaolinite clay lies between the range of 2.62 to $2.66[6,11]$. The inclusion of SF decreased the specific gravity of the soft kaolin.

A $5.3 \%$ reduction in specific gravity was determined with the addition of SF up to $6 \%$ by dry weight of soil, where it dropped to 2.50 from 2.64. The addition of the $3 \%, 6 \%$ and $9 \%$ of ESA to the kaolin6SF (K+6SF) mixture displayed an initial increment of specific gravity at $3 \%$ ESA content as ESA is coarse, and it was then reduced to 2.51. This is attributable to the rearrangement of soil particles as lighter SF and ESA were added. Therefore, it can be concluded that, the inclusion of $6 \%$ of SF and $6 \%$ of ESA can reduce the specific gravity of the kaolin.

\subsubsection{Atterberg Limit}

The moisture content for the penetration at $15 \mathrm{~mm}$, $20 \mathrm{~mm}$, and $25 \mathrm{~mm}$ was determined via Liquid Limit (LL) test. The LL and Plastic Limit (PL) for kaolin is $40.7 \%$ and $31.4 \%$ respectively, while the $\mathrm{PI}$ is $9.3 \%$. The $\mathrm{LL}$ and $\mathrm{PL}$ of SF are high, which is $90.5 \%$ and $80.5 \%$, respectively due to the water adsorption characteristic of the SF and causes the SF to be very friable. For ESA, the $\mathrm{LL}$ and $\mathrm{PL}$ recorded are $27.4 \%$ and $21.6 \%$ respectively with the $\mathrm{PI}$ value of $5.8 \%$. The $\mathrm{LL}$ and $\mathrm{PL}$ were initially reduced by $7.4 \%$ and $5.1 \%$, from $40.7 \%$ to $37.7 \%$ and from $31.4 \%$ to $29.8 \%$, respectively, with $2 \%$ of SF included. Then, both LL and $\mathrm{PL}$ value increased with the increment in SF content up to $6 \%$. The PI of the samples decreased with the addition of SF from $0 \%$ to $6 \%$ which proved that the clay content of the samples tested decreased with the addition of SF. For ESA, both LL and $P L$ value reduced by $17.0 \%$ and $15.4 \%$ respectively with ESA content up to $6 \%$. Further inclusion of ESA increased the $\mathrm{LL}$ and $\mathrm{PL}$ of the sample. The PI recorded a decreasing trend along with the increased ESA content which is attributable to the ability of ESA to coarsening the soil samples.
The $\mathrm{Pl}$ of the kaolin was reduced by $29.0 \%$ with the increased content of SF (from 9.3\% to 6.6\%) while an increment in ESA content, resulted in a $27.3 \%$ reduction of $\mathrm{PI}$ (from $6.6 \%$ to $4.8 \%$ ).

Based on the results obtained in Figure 3, both of the stabilizers can bind and flocculate the kaolin to become coarser particles, with a reduction of fine clay content via the cation exchange activity and pozzolanic reactions. These outcomes are similar to the previous studies conducted by other researchers, aforesaid in the previous section and paragraph [34]. The diminution in PI upon the addition of SF and ESA shows that the expansive characteristics of kaolin clay are reduced.

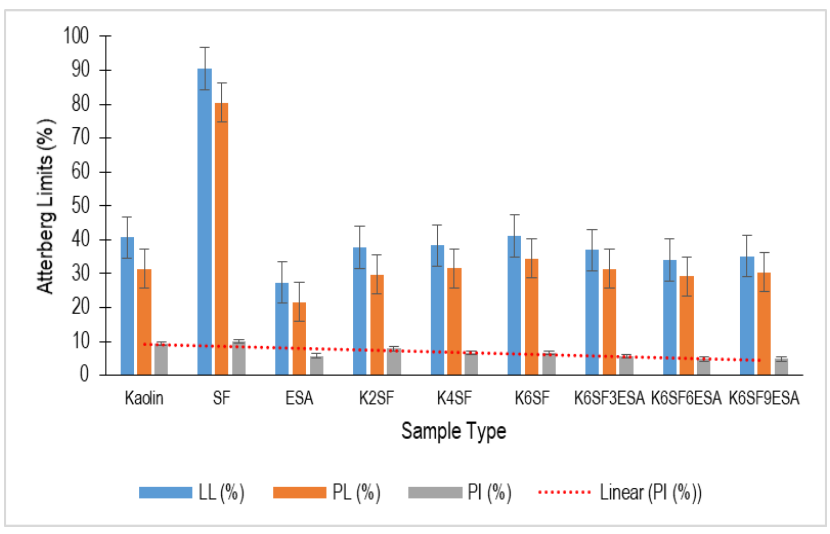

Figure 3 Relationship between types of a sample with sample Atterberg limits (\%)

\subsubsection{Standard Compaction Test}

The Maximum Dry Density (MDD) and Optimum Moisture Content (OMC) of untreated kaolin, SF, ESA, kaolin admixed with $2 \%, 4 \%$ and $6 \%$ of SFA and optimum kaolin-SF admixed with $3 \%, 6 \%$ and $9 \%$ of ESA content are determined via a series of Standard Proctor Compaction Test. The dry density initially showed a rising trend with the addition of water up to $19 \%$ and then dwindling. The MDD for untreated kaolin was $1.606 \mathrm{~g} / \mathrm{cm}^{3}$, with an OMC of $19 \%$. According to previous findings, MDD of clay soil is within the range of $1.4 \mathrm{~g} / \mathrm{cm}^{3}$ to $2.0 \mathrm{~g} / \mathrm{cm}^{3}$ while the $\mathrm{OMC}$ is ranging from $14 \%$ to $30 \%[6,11]$.

Therefore, the compaction results of the untreated kaolin obtained in this study are in the 
range of values stated by the previous researchers. The difficulty to form soil consistency in the PL test resulted in the unsuitable compaction test to be carried out for the SF and ESA. The result obtained from UCT recorded that the optimum SF content corresponding to the ultimate strength is at $6 \%$, thus, various percentages of ESA were then added to the kaolin admixed with 6\% SF for further strength improvement of untreated kaolin. Figure 4 shows the compaction curve of the kaolin-SF sample admixed with $0 \%, 3 \%, 6 \%$, and $9 \%$ of ESA. The compaction curve plotted to illustrate that the particle arrangement of the sample changed with the addition of ESA with high $\mathrm{CaO}$ content, thus the specific area of the sample is altered and more water is required for the chemical reaction among the fine particles, to set off the stabilization process. In general, the higher MDD of the soil shows a better performance in construction work, but it also means that the swelling pressure is high for expansive soil [6].

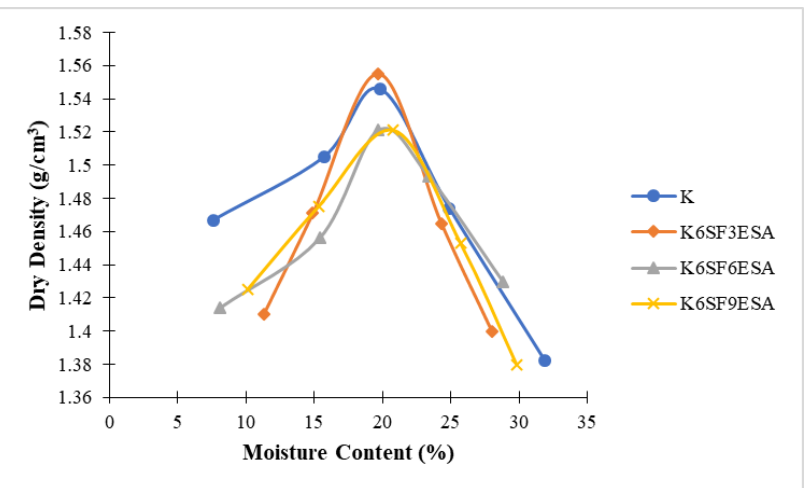

Figure 4 Compaction curve of kaolin admixed with $6 \% \mathrm{SF}$ and various percentage of ESA content (\%)

Figure 5 illustrate the correlation between MDD and $\mathrm{OMC}$ of the kaolin sample admixed with $6 \%$ of SF and various percentage of ESA.

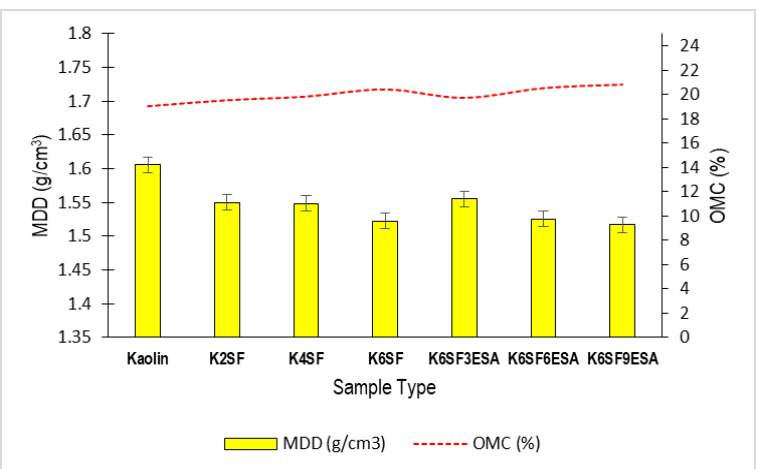

Figure 5 The correlation between MDD $\left(\mathrm{g} / \mathrm{cm}^{3}\right)$ and $\mathrm{OMC}$ (\%) of the kaolin sample admixed with $6 \%$ of SF and various percentage of ESA content (\%).

The MDD of the treated sample was initially increased to $1.555 \mathrm{~g} / \mathrm{cm}^{3}$ from $1.522 \mathrm{~g} / \mathrm{cm}^{3}$ at $3 \%$ of
ESA content and decreased to $1.525 \mathrm{~g} / \mathrm{cm}^{3}$ and $1.517 \mathrm{~g} / \mathrm{cm}^{3}$ at $6 \%$ and $9 \%$ of ESA content. The OMC of the treated sample decreased to $19.7 \%$ from $20.4 \%$ due to the adsorption capacity of ESA, attributable to the ESA porosity properties, and the increment in OMC with the inclusion of ESA up to $9 \%$ is due to the increased $\mathrm{CaO}$ content in the stabilized sample and thus more water is demanded [20] for the formation of $\mathrm{CSH}$ particles and pozzolanic reaction with the presence of SF. The trend of the graph obtained in this study is coherent to the study conducted by the previous researchers $[30,32]$. Based on the data discussed, it can be concluded that the addition of both SF and ESA can reduce the swelling tendency of the soft kaolin.

\subsection{Chemical Oxide Compositions}

Cementitious properties and pozzolanic reaction are the two crucial factors in stabilizing the soft clay soil. The pozzolanic reaction is a slow process and is mainly responsible for the development of strength. Generally, $\mathrm{CaO}$ and $\mathrm{SiO}_{2}$ are considered as the main constituents of cementitious material whereas both of the materials exhibit act as a binding agent when water is added. When hydration occurs, whereas with the addition of water, the $\mathrm{CaO}$ will react with the water and form calcium hydroxide, $\mathrm{Ca}(\mathrm{OH})_{2}$ as shown in equation (1).

$\mathrm{CaO}+\mathrm{H}_{2} \mathrm{O} \stackrel{\text { hydration }}{\longrightarrow} \mathrm{Ca}(\mathrm{OH})_{2}$

Next, the pozzolanic reaction will take place when the $\mathrm{SiO}_{2}$ from the SF and clay soil will react with $\mathrm{Ca}(\mathrm{OH})_{2}$ to form $\mathrm{CSH}$. Equation (2) shows the reaction when $S F$, the pozzolan reacts with $\mathrm{Ca}(\mathrm{OH})_{2}$. The long-term process of pozzolanic reaction is known to possess an enormous influence on the engineering properties of the soil, for instance, porosity, permeability and strength.

$\mathrm{Ca}^{2+}+2 \mathrm{OH}^{-}+\mathrm{SiO}_{2} \longrightarrow x \cdot \mathrm{CaSiO}_{3} \mathrm{H}_{2} \mathrm{O}$

The pozzolanic reaction depends on two factors which are the maximum amount of $\mathrm{Ca}(\mathrm{OH})_{2}$ that pozzolan can react with and the surface area of pozzolan. A greater surface area of pozzolan leads to the higher pozzolanic reactivity [35]. ESA is mainly made up of $\mathrm{CaO}$ while SF is comprised of more than $85 \%$ of $\mathrm{SiO}_{2}$. The particular gravity was somewhat diminished for eggshell powders because of their permeable nature. Empty openings exist between the calcite precious stones to permit the exchange of gases from the inward to the external side of the eggshell. The SF is considered an artificial pozzolan and is mainly comprised of silica glasses [36]. Since the pozzolans are low in $\mathrm{CaO}$ content, a material that contains a high percentage of $\mathrm{CaO}$ should be used. Therefore, as aforementioned in Table 1, the ESA is used in this study as the CaO content in ESA is high $(62.50 \%)$ and can act as a settling specialist to improve the strength of the untreated kaolin. Initially, 
the $\mathrm{CaCO}_{3}$ of the nature eggshell was transformed into $\mathrm{CaO}$ through the burning action using the furnace. This $\mathrm{CaO}$ was then contributed to the formation of cementitious components during soil stabilization. Table 5 shows the chemical oxide compositions of the untreated kaolin and treated kaolin samples.

\subsection{Mineralogy Characteristics}

XRD investigation distinguished the mineralogical substance of the untreated kaolin admixed with the ideal substance of the stabilizer $16 \%$ of SF and $6 \%$ of ESA). These sets of boundaries were chosen to additionally legitimize the previous examination on compound oxides piece. Based on Figure 6(a) and Figure $6(\mathrm{~b})$, the raw soil showed the presence of high clay minerals (quartz) and low aggregate minerals (muscovite). As the figure portrays there was a decrease in the most pinnacle powers of balanced out examples especially for test settled with the substance of the ideal stabilizer.

Table 5 Chemical oxide compositions of the untreated kaolin and treated kaolin samples

\begin{tabular}{ccccccc}
\hline \multirow{2}{*}{ Sample } & \multicolumn{7}{c}{ Compositions (\%) } \\
\cline { 2 - 7 } & $\mathbf{S i O}_{2}$ & $\mathbf{C a O}$ & $\mathbf{A l}_{2} \mathrm{O}_{3}$ & $\mathbf{K}_{\mathbf{2}} \mathbf{O}$ & $\mathbf{M g O}$ & $\mathbf{F e}_{2} \mathrm{O}_{3}$ \\
\hline Kaolin & 66.11 & 0.08 & 19.25 & 2.85 & 1.23 & 0.73 \\
(Control) & & & & & & \\
SF & 74.02 & 0.00 & 0.45 & 4.27 & 3.73 & 0.71 \\
ESA & 0.02 & 62.50 & 0.01 & 0.05 & 0.71 & 0.02 \\
K2SF & 67.59 & 0.05 & 18.88 & 2.88 & 1.28 & 0.73 \\
K4SF & 69.07 & 0.05 & 18.49 & 2.91 & 1.33 & 0.73 \\
K6SF & 70.55 & 0.08 & 18.12 & 2.94 & 1.38 & 0.73 \\
K6SF3ESA & 64.60 & 1.95 & 17.54 & 2.85 & 1.36 & 0.73 \\
K6SF6ESA & 62.62 & 3.82 & 16.97 & 2.77 & 1.35 & 0.69 \\
K6SF9ESA & 60.64 & 5.69 & 16.39 & 2.68 & 1.33 & 0.66 \\
\hline & & & & & &
\end{tabular}

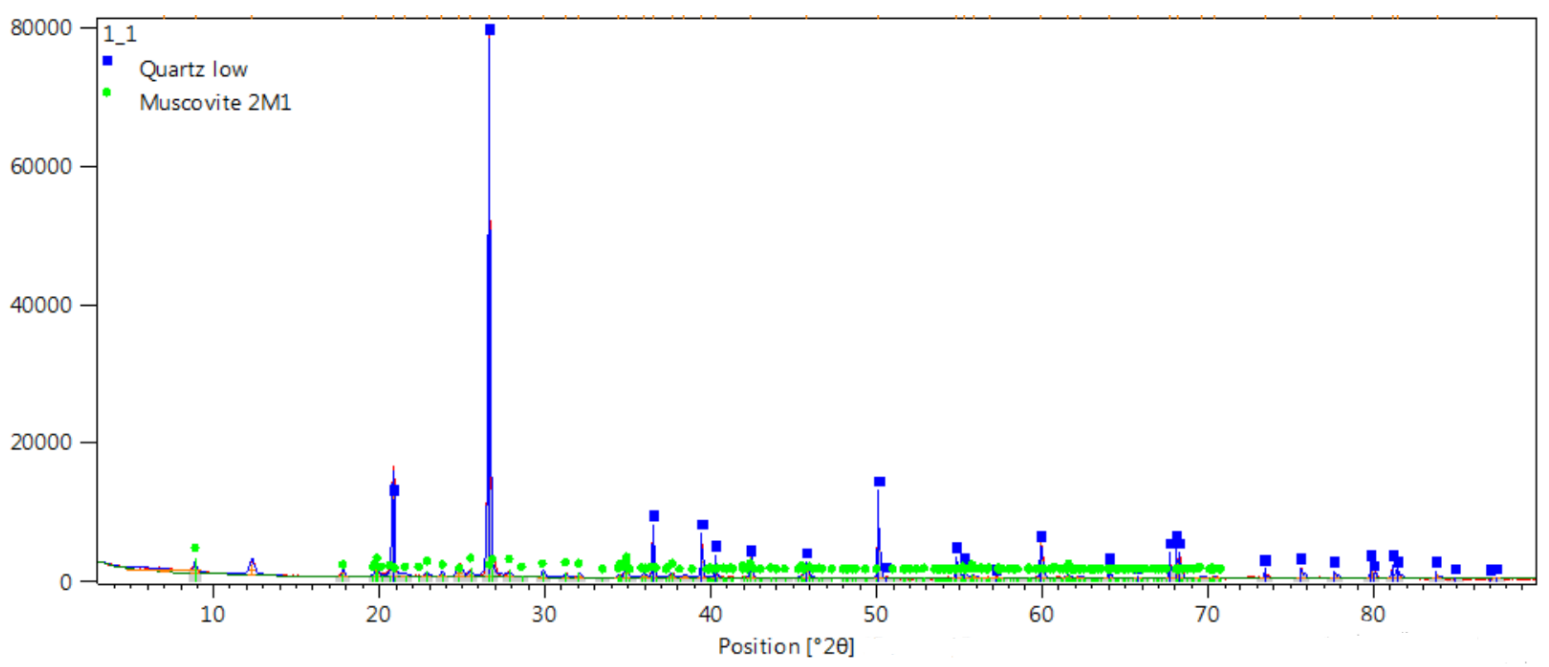

(a)

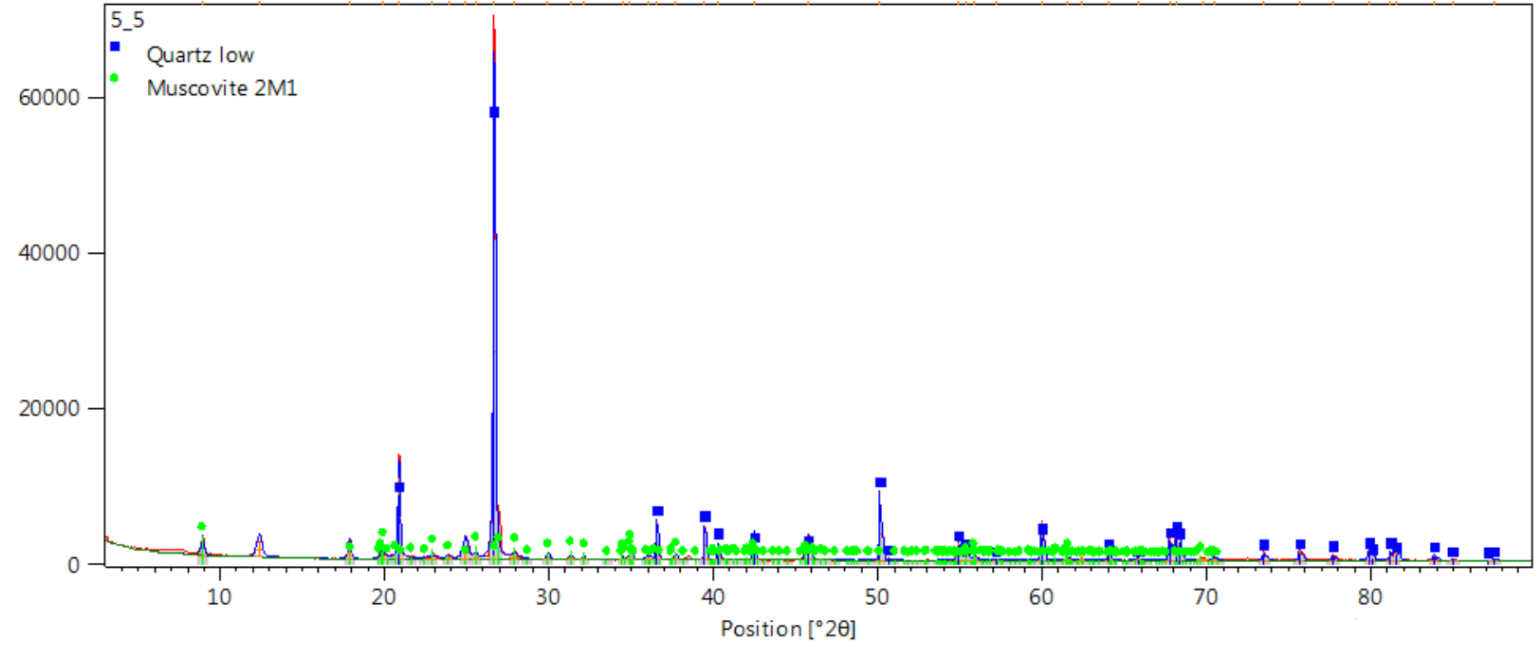

(b)

Figure 6 The XRD results for (a) untreated kaolin (b) treated kaolin with $6 \%$ of SF and $6 \%$ of ESA content 
The intensity of untreated kaolin shown in Figure 6(a) $(>60000)$ is reduced when the sample was stabilized with $6 \%$ of SF and $6 \%$ of ESA $(<60000)$ as shown in Figure $6(\mathrm{~b})$. Similar results have been reported by past researches [37]. This could be ascribed to the event of the pozzolanic response that brought about the decrease of the soil properties in settled material and lower top powers [37]. Furthermore, the shapelessness of the pozzolanic molecule was among the basic component that will be engaged with the optional hydration measure. The progressions of force at tops demonstrated that the incorporation of the SF and ESA impacted the arrangement of the glasslike silica. The crystallinity of silica is diminishing the pozzolanic reactivity of the material because of the capacity of the nebulous silica to partake in the hydration cycle to respond with the calcium hydroxide [14].

\subsection{Morphology Analysis}

Based on Table 6, for untreated kaolin, there is $52 \%$ of particles that are smaller than $0.075 \mathrm{~mm}$, which is classified as the fine sample with particle size ranges from $0.0008 \mathrm{~mm}$ to $0.063 \mathrm{~mm}$. The SF is a finer material as compared to Kaolin and presents in the size ranging from $0.00008 \mathrm{~mm}$ to $0.15 \mathrm{~mm}$ due to the $56 \%$ of SF particles passed the size of $0.075 \mathrm{~mm}$, where $44 \%$ of it retained above $0.075 \mathrm{~mm}$. Based on the percent finer at $4.75 \mathrm{~mm}$ and $0.075 \mathrm{~mm}$, LL and PI, the size of the SF used in this study can be characterized as $\mathrm{MH}$ (sandy/silty soil) with a high plasticity feature. According to AASHTO, SF is categorized as A-5 (fine silty) soil due to its $L L$ and $P L$ value. The ESA is a coarser material and exists in the size ranging from $0.063 \mathrm{~mm}$ to $0.3 \mathrm{~mm}$ with $26 \%$ of the particles passing the $0.075 \mathrm{~mm}$ sieve, while $74 \%$ of it retained above $0.075 \mathrm{~mm}$ sieve. Based on the percent finer at $4.75 \mathrm{~mm}$ and $0.075 \mathrm{~mm}, \mathrm{LL}$, and PI, the ESA is classified as SC (sandy-clay) particles and categorized as A-2-4 based on AASHTO classification due to its Atterberg limit characteristics.

Table 6 PSD of untreated kaolin, SF, ESA and kaolin stabilized with optimum stabilizer dosage

\begin{tabular}{lcccc}
\hline \multirow{2}{*}{ Sample } & \multicolumn{4}{c}{ Compositions (\%) } \\
\cline { 2 - 5 } & Kaolin & SF & ESA & $\begin{array}{c}\text { Kaolin + 6\% SF + 6\% } \\
\text { ESA }\end{array}$ \\
\hline$>4.75$ & 0 & 0 & 0 & 0 \\
$0.075-4.75$ & 48 & 44 & 74 & 66 \\
$\leq 0.075$ & 52 & 56 & 26 & 34 \\
\hline
\end{tabular}

The inclusion of SF and ESA to the soft kaolin prompt the reshuffling of soil particle matrix, forming a coarser kaolin-SF-ESA (K-SF-ESA) mixture where the PSD curve of the treated kaolin as shown in Figure 7 shifted slightly to the coarser right side. The treated soft kaolin is classified as a sand-silt mixture (SM) and is categorized as sandy-silt (A-2-4) in AASHTO. It consists of $0 \%$ gravel, $66 \%$ sand and $44 \%$ clay and silt (Table 6).

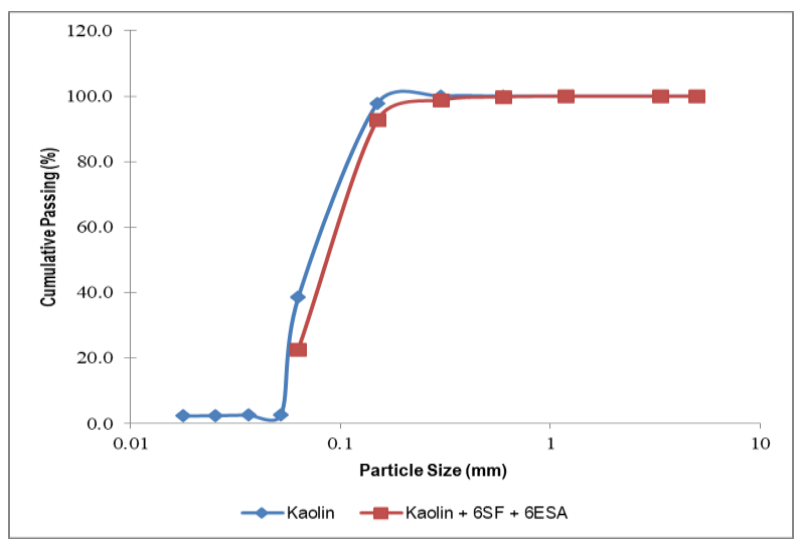

Figure 7 PSD curve of untreated kaolin and treated kaolin with an optimum dosage of stabilizers (6\% SF \& 6\% ESA)

Based on the UCT result, the optimum stabilizer content corresponding to maximum USS, qu is $6 \% \mathrm{SF}$ and $6 \%$ ESA. The treated kaolin sample is coarser than untreated kaolin with $34 \%$ of particles were smaller than $0.075 \mathrm{~mm}$. Based on the PSD curve plotted in Figure 7, the treated kaolin shifted slightly to the right side (coarser indication) which is attributable to the inclusion of finer SF and coarser ESA that caused the reshuffling of soil particles matrix. The treated kaolin is classified as SM (sand-silt) mixture and also characterized in group A-2-4 (sandy-silt or sandy-clay) by referring to the AASHTO classification. The classification outcomes by using USCS and AASHTO classification for all of the materials are similar.

\subsection{Shear Strength Analysis}

The initial $q_{u}$ value of untreated soft kaolin is 42.11 $\mathrm{kN} / \mathrm{m}^{2}$. The qu value increased with the initial increment of SF content and recorded the highest improvement at $39.6 \%$ by using $6 \%$ of SF content by the dry weight of the soil as shown in Figure 8 . This marks $6 \%$ SF as the optimum content to be used with ESA for further strength improvement.

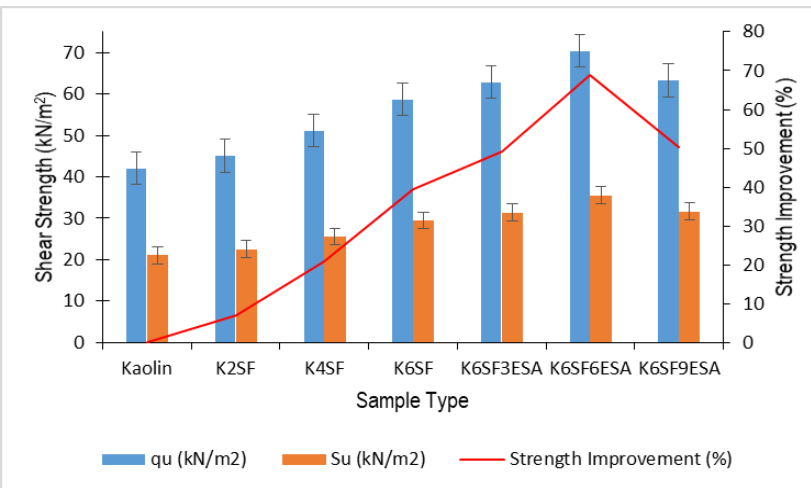

Figure 8 PSD curve of untreated kaolin and treated kaolin with an optimum dosage of stabilizers (6\% SF \& 6\% ESA) 
A $3 \%, 6 \%$ and $9 \%$ of ESA were later added to the soft kaolin admixed with $6 \% \mathrm{SF}$ to examine the performance in stabilizing the soft kaolin. The incorporation of the ESA up to $6 \%$ increased the qu value of soft kaolin to $71.10 \mathrm{kN} / \mathrm{m}^{2}$, where a maximum improvement of $68.8 \%$ is recorded. The further incorporation of ESA content to $9 \%$ decreased the qu value of soft kaolin due to displacement of soil particles. Besides, due to the excess ESA content, the bonding form between the particles is weak. The results of UCT implies that the addition of SF and ESA gradually increased the formation of $\mathrm{CSH}$ and prompt the pozzolanic reaction that contributes to the enhancement in strength properties of soft kaolin. Figure 9 illustrate the stress-strain graph of five (5) samples of the kaolin treated with $6 \%$ of SF and $6 \%$ of ESA content (K6SF6ESA).

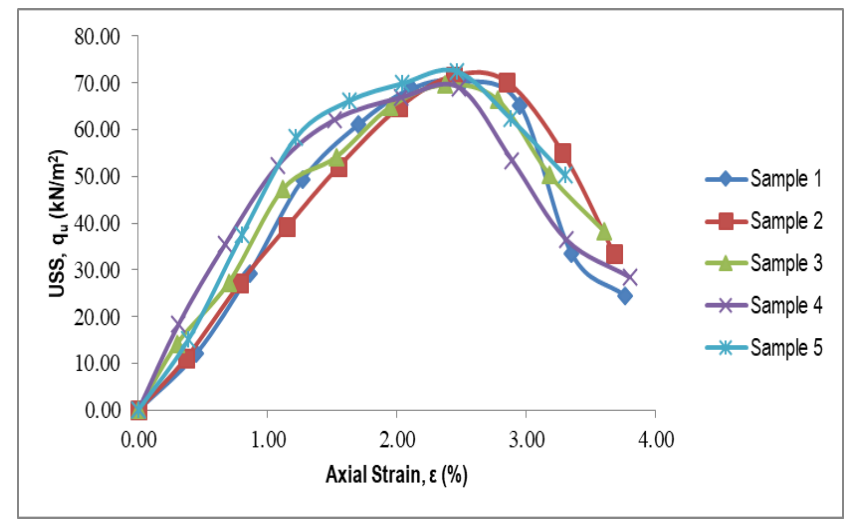

Figure 9 Stress-strain graph of the K6SF6ESA sample

Figure 10(a) and Figure 10(b) are the typical failure mode that was observed in this study. Figure $10(a)$ is shown the shear failure of the compacted soil sample, for both untreated and treated samples, where the compacted soil cracks vertically from the upper layer to the bottom upon the application of compression load while Figure 10(b) exemplifies the bulging failure, where the failure occurs at the weak layer of soil. The failure in the soil is a complicated circumstance that can be caused by various factors

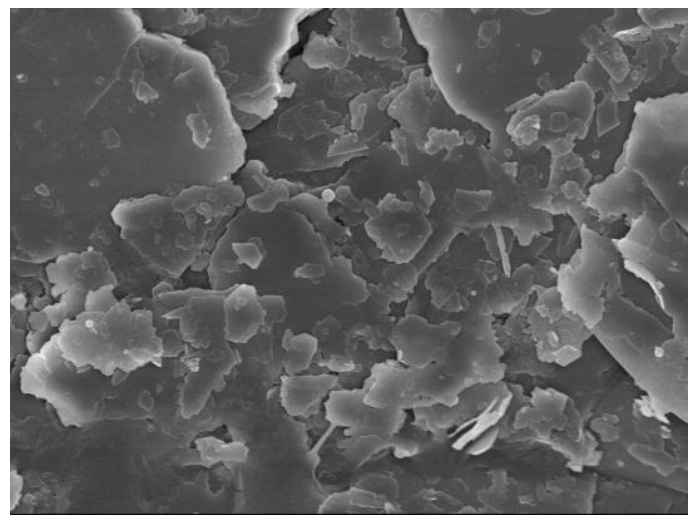

(a) and have a close relationship with the brittleness and ductility of the soil [11]. The variables including the confining pressure, pore pressure, rate of strain, temperature, fluid chemistry, modal composition, particle size, porosity and so on [11].

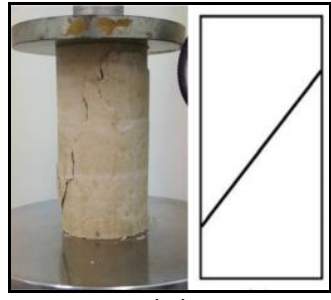

(a)

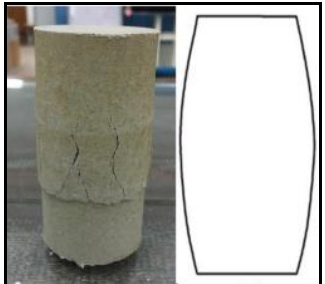

(b)
Figure 10 Compacted soil sample of (a) shear failure (b) bulging failure

\subsection{Microstructural Characterization}

Field Emission Scanning Electron Microscope (FESEM) images under $\times 10000$ magnification of untreated kaolin, raw SF, and raw ESA are shown in Figure 11 (a), Figure 11 (b), and Figure 11 (c). Based on Figure 11 (a), the raw kaolin has a flaky shape microstructure. Figure $11(\mathrm{~b})$ shows that the SF particle was composed of a fine spherical shape with a particle size of several hundred nanometers. The ESA powder particles seemed to have a rugged, sporadic morphology and a fluctuating molecule size appropriation because of the pounding treatment directed as shown in Figure 11(c). The eggshell natural layer was not noticeable inside the examples.

Figure 12(a), Figure 12(b), Figure 12(c) and Figure 12 (d) illustrate the FESEM image of treated kaolin with $6 \%$ of SF and $6 \%$ of ESA under $\times 10000$ magnification, $\times 15000$ magnification, $\times 30000$ magnification and x100 000 magnification respectively. Based on the figure shown, it clearly shows that the SF and ESA particles are present in the kaolin as the figures illustrate the spherical shape of SF and a jagged and irregular shape of ESA binding together with the flaky shape of the kaolin.

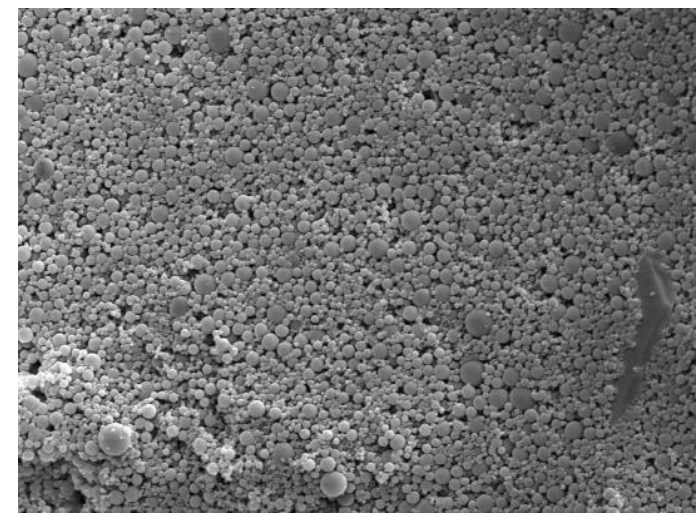

(b) 


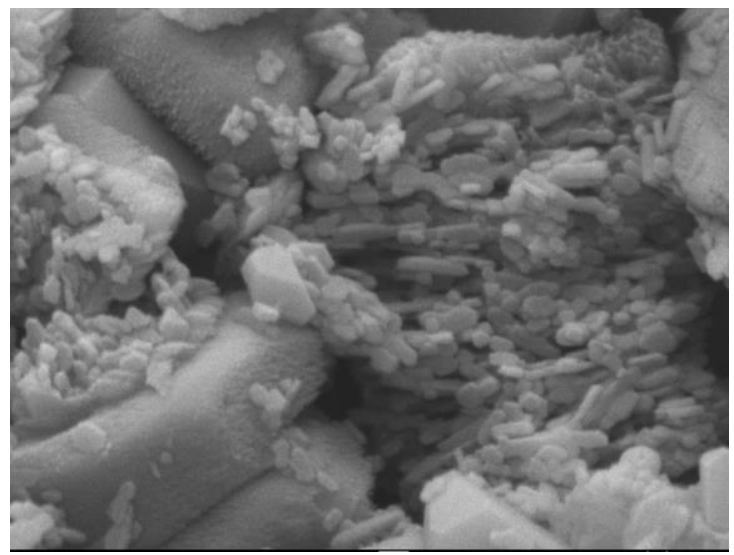

(c)

Figure 11 FESEM images under x10 000 magnification of a (a) untreated kaolin, (b) SF, and (c) ESA

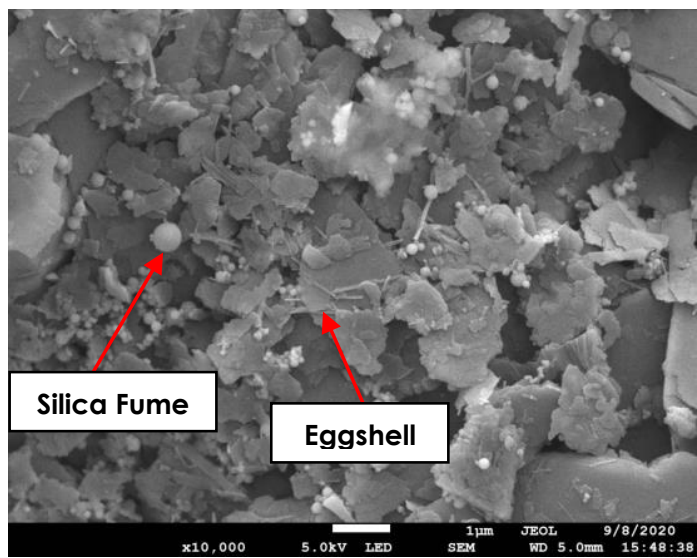

(a)

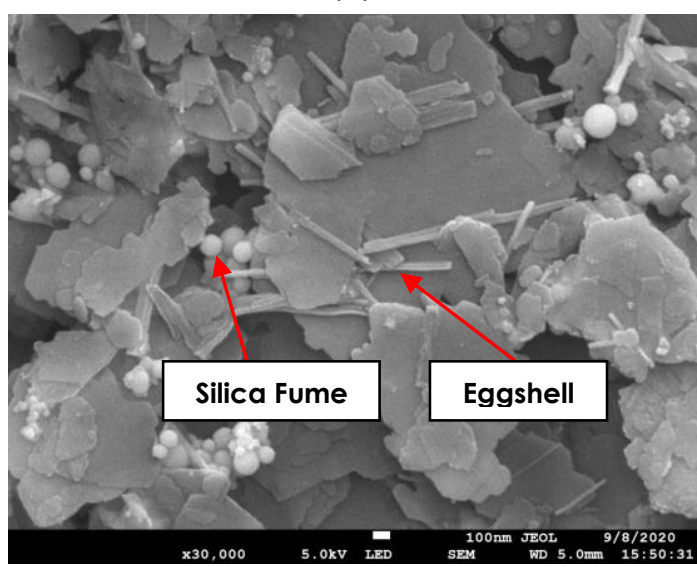

(c)

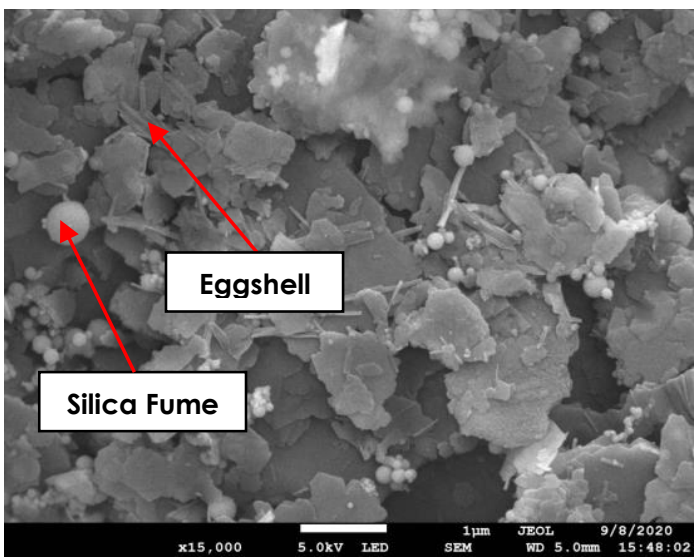

(b)

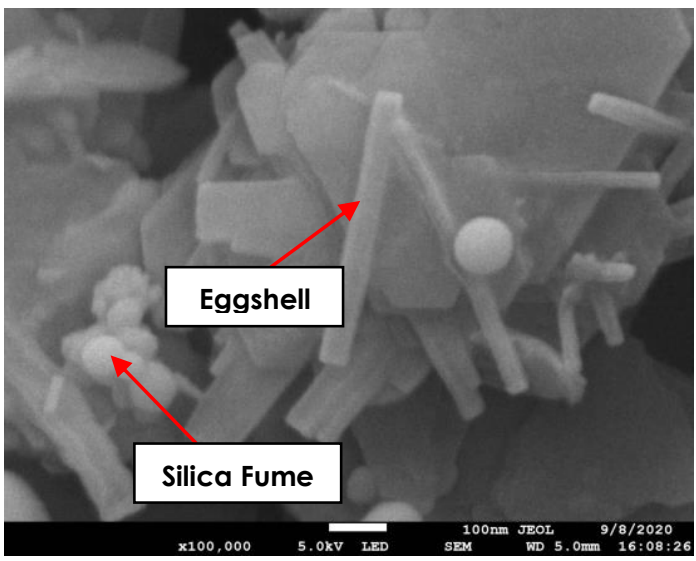

(d)

Figure 12 FESEM images of treated kaolin under (a) x10 000, (b) 15000, (c) 30000 and (d) 100000 magnification

\subsection{Correlation Analysis}

The correlations of the engineering properties (i.e specific gravity, Atterberg limit, Standard Proctor Compaction test and UCT) of soft kaolin with the varying SF and ESA content were established in this study. The correlations equation of the four (4) parameters investigated in this study is crucial to predict the best model for optimum usage of stabilizers of SF and ESA content. Thus, the equation will be a significant guideline for the soil stabilization method provided in this study. The correlation equations of the four (4) parameters studied are tabulated in Table 7. 
Table 7 PSD of untreated kaolin, SF, ESA and kaolin stabilized with optimum stabilizer dosage

\begin{tabular}{|c|c|c|c|}
\hline Test & Correlation equation & $\mathbf{R}^{2}$ value & Variation (\%) \\
\hline \multirow{2}{*}{ Specific gravity } & $G_{s}=0.0225 S F^{2}+2.615$ & 0.8248 & 82.48 \\
\hline & $G_{s}=-0.0036 E S A^{2}+0.0315 E S A+2.5095$ & 0.7029 & 70.29 \\
\hline \multirow{6}{*}{ Atterberg Limit } & $\mathrm{LL}=0.3625 \mathrm{SF}^{2}-2.085 \mathrm{SF}+40.63$ & 0.9887 & 98.87 \\
\hline & $P L=0.2813 S F^{2}-1.1325 S F+31.285$ & 0.9770 & 97.70 \\
\hline & $P I=-0.465 S F+9.02$ & 0.9033 & 90.33 \\
\hline & $\mathrm{LL}=0.1456 \mathrm{ESA}^{2}-1.996 \mathrm{ESA}+41.234$ & 0.9874 & 98.74 \\
\hline & $P L=0.1194 E_{E S}{ }^{2}-1.5583 E S A+34.625$ & 0.9798 & 97.98 \\
\hline & $P I=-0.2019 E S A+6.3728$ & 0.8913 & 89.13 \\
\hline \multirow{4}{*}{$\begin{array}{l}\text { Standard Proctor Compaction } \\
\text { Test }\end{array}$} & $\rho_{d(\max )}=-0.0128 S F+1.5944$ & 0.8641 & 86.41 \\
\hline & $W_{o p t}=0.225 S F+19$ & 0.9854 & 98.54 \\
\hline & $\rho_{d(\max )}=-0.0011 \mathrm{ESA}^{2}+0.0088 \mathrm{ESA}+1.5263$ & 0.5908 & 59.08 \\
\hline & $W_{o p t}=0.0278 \mathrm{ESA}^{2}-0.1833 \mathrm{ESA}+20.3$ & 0.6923 & 69.23 \\
\hline \multirow{2}{*}{$\begin{array}{l}\text { Unconfined Compression Test } \\
\text { (UCT) }\end{array}$} & $S_{U}=1.4045 S F+20.449$ & 0.9675 & 96.75 \\
\hline & $S_{U}=-0.1642 \mathrm{ESA}^{2}+1.8405 \mathrm{ESA}+28.892$ & 0.7393 & 73.93 \\
\hline
\end{tabular}

From the correlation equation tabulated in Table 7, it can be deduced that, with the higher value of the coefficient of determination ( $R^{2}$ value), the percentage of the variations of the four (4) parameters observed can be predicted by the inclusion of the SF and ESA as soil stabilizers. Based on the regression statistics established in the study, the coefficient of determination ( $R^{2}$ value) for all parameters investigated are above 0.5. Hence, it can be proven that $50 \%$ of the variation in the parameters studied (specific gravity, Atterberg limit, compaction and shear strength) can be explained by the inclusion of SF content and ESA content. Therefore, the correlation established is the best model to be used to predict the optimum dosage usage of stabilizers (SF and ESA content).

\subsection{CONCLUSION}

Based on the experimental results and data analysis carried out in this study, the decreasing in the specific gravity of the stabilized kaolin mixture with SF and ESA indicates that the soil particles matrix is reshuffled and a lighter soil mixture is formed. A maximum reduction of $48.4 \%$ in $\mathrm{Pl}$ of the stabilized kaolin mixture with SF and ESA implies that clay content lessened and expansive characteristics of soft clay are effectively reduced.

Besides, the reduction in MDD is ascribable to the reshuffling of the soil particles matrix while OMC increased as more water is required to form the $\mathrm{CSH}$ compounds and to promote the pozzolanic reaction between the stabilizers and kaolin clay. The incorporation of SF and ESA can effectively improve the strength properties of soft kaolin and an ultimate enhancement of $68.8 \%$ is attained at $6 \%$ SF and $6 \%$ ESA content, which indicates the optimum stabilizers content. The inclusion of SF and ESA coarsen the particles of soft kaolin mixture and the soil classification change to SM and A-2-4 with the $15 \%$ reduction in fine contents.

\section{Acknowledgement}

The authors would like to acknowledge the Universiti Malaysia Pahang (UMP) and Hokoku Engineering for financing this research through the UMP Flagship Grant Scheme, Project Number RDU172205, UMP Short Term Grant, Project Number RDU190344, UMP Matching Grant, Project Number RDU202701, Hokoko International Grant, Project Number UIC201503 and Postgraduate Research Grant Scheme (PGRS), Project Number PGRS2003185, respectively. The cooperation given by all parties involved in this research is greatly acknowledged.

\section{References}

[1] Afrin, H. 2014. A Review on Different Types Soil Stabilization Techniques. International Journal of Transportation Engineering and Technology. 3(2): 19-24.

[2] Latifi, N., Eisazadeh, A., Marto, A., \& Meehan, C. L. 2017. Tropical Residual Soil Stabilization: A Powder Form Material for Increasing Soil Strength. Construction and Building Materials. 147: 827-836

DOI: https://doi.org/10.1016/j.conbuildmat.2017.04.115.

[3] Liu, Y., Chang, C. W., Namdar, A., She, Y., Lin, C. H., Yuan, X., \& Yang, Q. 2019. Stabilization of Expansive Soil Using Cementing Material from Rice Husk Ash and Calcium Carbide Residue. Construction and Building Materials. 221(2): 1-11.

DOI: https://doi.org/10.1016/j.conbuildmat.2019.05.157.

[4] Blayi, R., Sherwani, A., Ibrahim, H., Faraj, R., \& Daraei, A. 2020. Strength Improvement of Expansive Soil by Utilizing Waste Glass Powder. Case Studies in Construction Materials. 13: e00427.

[5] Abbey, S., Eyo, E., Okeke, C., \& Ngambi, S. 2021. Experimental Study on the Use of RoadCem Blended with by-product Cementitious Materials for Stabilisation Of Clay Soils. Construction and Building Materials. 280: 122476.

[6] Li, Y. 2021. Effect of Post-fire Curing and Silica Fume on Permeability of Ultra-high Performance Concrete. Construction and Building Materials. 290: 123175. DOI: https://doi.org/10.1016/j.conbuildmat.2021.123175.

[7] Obianyo, I., Onwualu, A., \& Soboyejo, A. 2020. Mechanical Behaviour of Lateritic Soil Stabilized with Bone Ash and Hydrated Lime for Sustainable Building Applications. Case Studies in Construction Materials. 12: e00331. 
[8] Ghadir, P., \& Ranjbar, N. 2018. Clayey Soil Stabilization using Geopolymer and Portland Cement. Construction and Building Materials. 188: 361-371

[9] Bao, X., Huang, Y., Jin, Z., Xiao, X., Tang, W., Cui, H., \& Chen, X. 2021. Experimental Investigation on Mechanical Properties of Clay Soil Reinforced with Carbon Fiber. Construction and Building Materials. 280: 122517.

[10] Phanikumar, B., \& Ramanjaneya Raju, E. 2020. Compaction and Strength Characteristics of An Expansive Clay Stabilised with Lime Sludge and Cement. Soils and Foundations. 60(1): 129-138.

[11] Alrubaye, A. J., Hasan, M. and Fattah, M. Y. 2017. Stabilization of Soft Kaolin Clay with Silica Fume and Lime. International Journal of Geotechnical Engineering. 11(1): 90-96.

[12] Sharma, L., Sirdesai, N., Sharma, K., \& Singh, T. 2018. Experimental Study to Examine the Independent Roles of Lime and Cement on the Stabilization of a Mountain Soil: A Comparative Study. Applied Clay Science. 152: 183-195.

[13] Hsu, S., Chi, M., Huang, R. 2018. Effect of Fineness and Replacement Ratio of Ground Fly Ash on Properties of Blended Cement Mortar. Constr. Build. Mater. 176: $250 \mathrm{e} 258$

[14] Ismail, A. H., Kusbiantoro, A., Chin, S. C., Muthusamy, K., Islam, M., \& Tee, K. F. 2020. Pozzolanic Reactivity and Strength Activity Index of Mortar Containing Palm Oil Clinker Pretreated with Hydrochloric Acid. Journal of Cleaner Production. 242: 118565. DOI: https://doi.org/10.1016/j.jclepro.2019.118565.

[15] Andrew, R. M. 2018. Global CO2 Emissions from Cement Production. Earth Syst. Sci. Data. 10(1): 195.

[16] Hu, W., Nie, Q., Huang, B., Shu, X. 2019. Investigation of the Strength Development of Cast-in-place Geopolymer Piles with Heating Systems. J. Clean. Prod. 215: 1481e1489.

[17] Hanif, A., Parthasarathy, P., Ma, H., Fan, T., Li, Z. 2017a. Properties Improvement of Fly Ash Cenosphere Modified Cement Pastes using Nano Silica. Cement Concr. Compos. 81: 35e48.

[18] Hanif, A., Kim, Y., Lu, Z., Park, C. 2017b. Early-age Behavior of Recycled Aggregate Concrete under Steam Curing rme. J. Clean. Prod. 152: 103e114.

[19] Kim, Y., Hanif, A., Usman, M., Munir, M. J., Kazmi, S. M. S. Kim, S. 2018. Slag Waste Incorporation in High Early Strength Concrete as Cement Replacement: Environmental Impact and Influence on Hydration \& Durability Attributes. J. Clean. Prod. 172: 3056e3065.

[20] Jafer, H., Atherton, W., Sadique, M., Ruddock, F., \& Loffill. E. 2018. Stabilisation of Soft Soil using Binary Blending of High Calcium Fly Ash and Palm Oil Fuel Ash. Applied Clay Science. 152: 323-332.

[21] Karim, M. R., Chowdhury, F. I., Zabed, H., Saidur, M. R. 2018. Effect of Elevated Temperatures on Compressive Strength and Microstructure of Cement Paste Containing Palm Oil Clinker Powder. Constr. Build. Mater. 183: $376 \mathrm{e} 383$

[22] Inazumi, S., Intui, S., Jotisankasa, A., Chaiprakaikeow, S., \& Shinsaka, T. 2020. Applicability of Mixed Solidification Material based on Inorganic Waste as Soil Stabilizer. Case Studies In Construction Materials. 12: e00305.

[23] Phua, Y., \& Røyne, A. 2018. Bio-cementation through Controlled Dissolution and Recrystallization of Calcium Carbonate. Construction and Building Materials. 167: 657668. DOI: https://doi.org/10.1016/j.jclepro.2019.118565.

[24] Poorveekan, K., Ath, K. M. S., Anburuvel, A., \& Sathiparan, N. 2021. Investigation of the Engineering Properties of
Cementless Stabilized Earth Blocks with Alkali-activated Eggshell and Rice Husk Ash as a Binder. Construction and Building Materials. 277: 122371.

DOI: https://doi.org/10.1016/j.conbuildmat.2021.122371.

[25] Hamideh, F., \& Akbar, A. 2018. Application of Eggshell Wastes as Valuable and Utilizable Products: A Review. Research in Agricultural Engineering. 64(2): 104-114. DOI: https://doi.org/10.17221/6/2017-rae.

[26] Sathiparan, N. 2021. Utilization Prospects Of Eggshell Powder in Sustainable Construction Material - A Review. Construction and Building Materials. 293: 123465.

[27] Hamada, H., Tayeh, B., Yahaya, F., Muthusamy, K., \& AlAttar, A. 2020. Effects of Nano-palm Oil Fuel Ash and Nano-eggshell Powder on Concrete. Construction and Building Materials. 261: 119790. DOI: https://doi.org/10.1016/j.conbuildmat.2020.119790.

[28] Ofuyatan, O. M., Adeniyi, A. G., Ijie, D., Ighalo, J. O., \& Oluwafemi, J. 2020. Development of High-performance Self Compacting Concrete using Eggshell Powder and Blast Furnace Slag as Partial Cement Replacement. Construction and Building Materials. 256: 119403. DOI: https://doi.org/10.1016/j.conbuildmat.2020.119403.

[29] Tiong, H. Y., Lim, S. K., Lee, Y. L., Ong, C. F., \& Yew, M. K. 2020. Environmental Impact and Quality Assessment of using Eggshell Powder Incorporated in Lightweight Foamed Concrete. Construction and Building Materials. 244: 118341. DOI: https://doi.org/10.1016/j.conbuildmat.2020.118341.

[30] Muthu Kumar and Tamilarasan. 2014. Effect of Eggshell Powder in the Index and Engineering Properties of Soil. International Journal of Engineering Trends and Technology (IJETT). 11 (7): 319-321.

[31] Khan, M., \& Ali, M. 2019. Improvement in Concrete Behavior with Fly Ash, Silica-fume and Coconut Fibres. Construction and Building Materials. 203: 174-187 DOI: https://doi.org/10.1016/j.conbuildmat.2019.01.103.

[32] Wang, X., Huang, J., Dai, S., Ma, B., \& Jiang, Q. 2020. Investigation of Silica Fume as Foam Cell Stabilizer for Foamed Concrete. Construction and Building Materials. 237: 117514

DOI: https://doi.org/10.1016/j.conbuildmat.2019.117514.

[33] Brescia-Norambuena, L., González, M., Avudaiappan, S. Saavedra Flores, E. I., \& Grasley, Z. 2021. Improving Concrete Underground Mining Pavements Performance through the Synergic Effect of Silica Fume, Nanosilica, and Polypropylene Fibers. Construction and Building Materials. 285: 122895 DOI: https://doi.org/10.1016/j.conbuildmat.2021.122895.

[34] Al-soudany, K. 2018. Improvement of Expansive Soil by using Silica. Kufa Journal of Engineering. 9(1): 222-239.

[35] Chong, J. Z., Sutan, N. M. and Yakub, I. 2012. Characterization of Early Pozzolanic Reaction of Calcium Hydroxide and Calcium Silicate Hydrate for Nanosilica Modified Cement Paste. UNIMAS e-Journal of Civil Engineering. 4(3): 6-10.

[36] Müller, C. J. 2005. Pozzolanic Activity of Natural Clay Minerals with Respect to Environmental Geotechnics. Doctorial Thesis. Swiss Federal Institute of Technology Zurich, Switzerland.

[37] Modarres, A., \& Nosoudy, Y. 2015. Clay Stabilization using Coal Waste and Lime - Technical and Environmental Impacts. Applied Clay Science. 116-117: 281-288. 